\title{
Microbially-accelerated consolidation of oil sands tailings. Pathway l: changes in porewater chemistry
}

\author{
Tariq Siddique ${ }^{1 *}$, Petr Kuznetsov ${ }^{1}$, Alsu Kuznetsova ${ }^{1}$, Nicholas Arkell ${ }^{1}$, Rozlyn Young ${ }^{2}$, Carmen Li ${ }^{2}$, \\ Selma Guigard ${ }^{3}$, Eleisha Underwood ${ }^{3}$ and Julia M. Foght ${ }^{2}$
}

${ }^{1}$ Department of Renewable Resources, University of Alberta, Edmonton, AB, Canada

2 Department of Biological Sciences, University of Alberta, Edmonton, AB, Canada

${ }^{3}$ Department of Civil and Environmental Engineering, University of Alberta, Edmonton, AB, Canada

Edited by:

Jason Raymond, Arizona State

University, USA

Reviewed by:

Amy Michele Grunden, North

Carolina State University, USA

Mark Alexander Lever, Aarhus

University, Denmark

*Correspondence:

Tariq Siddique, Department of

Renewable Resources, University of

Alberta, 442-Earth Sciences

Building, Edmonton, AB T6G 2E3,

Canada

e-mail: tariq.siddique@ualberta.ca
Dispersed clay particles in mine tailings and soft sediments remain suspended for decades, hindering consolidation and challenging effective management of these aqueous slurries. Current geotechnical engineering models of self-weight consolidation of tailings do not consider microbial contribution to sediment behavior, however, here we show that microorganisms indigenous to oil sands tailings change the porewater chemistry and accelerate consolidation of oil sands tailings. A companion paper describes the role of microbes in alteration of clay chemistry in tailings. Microbial metabolism in mature fine tailings (MFT) amended with an organic substrate (hydrolyzed canola meal) produced methane $\left(\mathrm{CH}_{4}\right)$ and carbon dioxide $\left(\mathrm{CO}_{2}\right)$. Dissolution of biogenic $\mathrm{CO}_{2}$ lowered the $\mathrm{pH}$ of amended MFT to $\mathrm{pH} 6.4$ vs. unamended MFT (pH 7.7). About $12 \%$ more porewater was recovered from amended than unamended MFT during 2 months of active microbial metabolism, concomitant with consolidation of tailings. The lower $\mathrm{pH}$ in amended MFT dissolved carbonate minerals, thereby releasing divalent cations including calcium $\left(\mathrm{Ca}^{2+}\right)$ and magnesium $\left(\mathrm{Mg}^{2+}\right)$ and increasing bicarbonate $\left(\mathrm{HCO}_{3}^{-}\right)$in porewater. The higher concentrations increased the ionic strength of the porewater, in turn reducing the thickness of the diffuse double layer (DDL) of clay particles by reducing the surface charge potential (repulsive forces) of the clay particles. The combination of these processes accelerated consolidation of oil sands tailings. In addition, ebullition of biogenic gases created transient physical channels for release of porewater. In contrast, saturating the MFT with non-biogenic $\mathrm{CO}_{2}$ had little effect on consolidation. These results have significant implications for management and reclamation of oil sands tailings ponds and broad importance in anaerobic environments such as contaminated harbors and estuaries containing soft sediments rich in clays and organics.

Keywords: methanogenesis, porewater chemistry, biogeochemical pathways, consolidation, oil sands tailings

\section{INTRODUCTION}

The oil sands in Alberta, Canada are the world's third largest proven reserve comprising $\sim 170$ billion barrels of recoverable bitumen, with production expected to surpass 3.5 million barrels $\mathrm{day}^{-1}$ by 2020 . Bitumen is extracted from surfacemined ores using hot water and hydrocarbon solvent (Schramm et al., 2000), generating $\sim 1$ million $\mathrm{m}^{3}$ fluid fine tailings day $^{-1}$ that are deposited and retained in tailings ponds. The current total volume ( $>920$ million $\mathrm{m}^{3}$ ) and surface area $\left(\sim 182 \mathrm{~km}^{2}\right)$ of the ponds will continue to increase with resource exploitation (Alberta Environment and Sustainable Resource Development, 2013) (http://www.aer.ca/rules-and-regulations/ directives/tailings-plans-2012). Two major challenges plague the oil sands surface mining industry: (1) recovering water from tailings for re-use (7.5-10 barrels of water for every barrel of bitumen produced), so as to reduce the need for fresh water, and (2) consolidating the tailings solids to decrease the volume of stored tailings for subsequent reclamation.
The tailings deposited into ponds (initially at $\sim 10 \mathrm{wt} \%$ solids) settle by gravity in 2-4 years to form mature fine tailings (MFT, $\sim 30 \mathrm{wt} \%$ solids), a colloidal suspension comprising slightly alkaline water, silt, clay, unrecovered bitumen ( $\sim \mathrm{wt} \%)$ and residual solvent $(<1 \mathrm{wt} \%)$ such as naphtha, a mixture of $\mathrm{C}_{3}-\mathrm{C}_{14}$ aliphatic and monoaromatic hydrocarbons. MFT then requires decades to consolidate to $>60 \mathrm{wt} \%$ solids (Fedorak et al., 2003; Jeeravipoolvarn et al., 2009) through close packing of clay particles accompanied by interstitial water (porewater) expression to form a "cap water" layer. Tailings ponds harbor indigenous microbial communities (Penner and Foght, 2010; Siddique et al., $2011,2012)$ that anaerobically biodegrade organic compound, such as solvent hydrocarbons, to methane $\left(\mathrm{CH}_{4}\right)$ plus carbon dioxide $\left(\mathrm{CO}_{2}\right)$ (Siddique et al., 2006, 2007, 2011). Biogenic gas production has been associated with accelerated consolidation of MFT and recovery of porewater both in situ and in the laboratory (Fedorak et al., 2003; Bressler et al., 2010). To date, only simple physical mechanisms such as creation of transient 
channels for water transport by biogenic gas bubbles (Brown et al., 2013; Voordouw, 2013) have been proposed to explain this phenomenon, but this mechanism inadequately describes consolidation when gas is formed but ebullition is minimal.

Because biodensification is slow in situ when supported solely by endogenous substrates, we amended MFT with low concentrations of labile organic substrates to enhance anaerobic microbial activity and accelerate the processes ex situ. Here we describe a laboratory study conducted using 50-L columns (Figure 1). The results reveal biogeochemical reactions that impact the chemistry of three tailings components-porewater, expressed porewater (cap water) and solids - and accelerate consolidation of MFT. We describe how microbial metabolism alters the chemistry of porewater that in turn influences consolidation of clay particle suspensions. A companion paper (Siddique et al., 2014) describes microbe:mineral interactions in the solids fraction. The

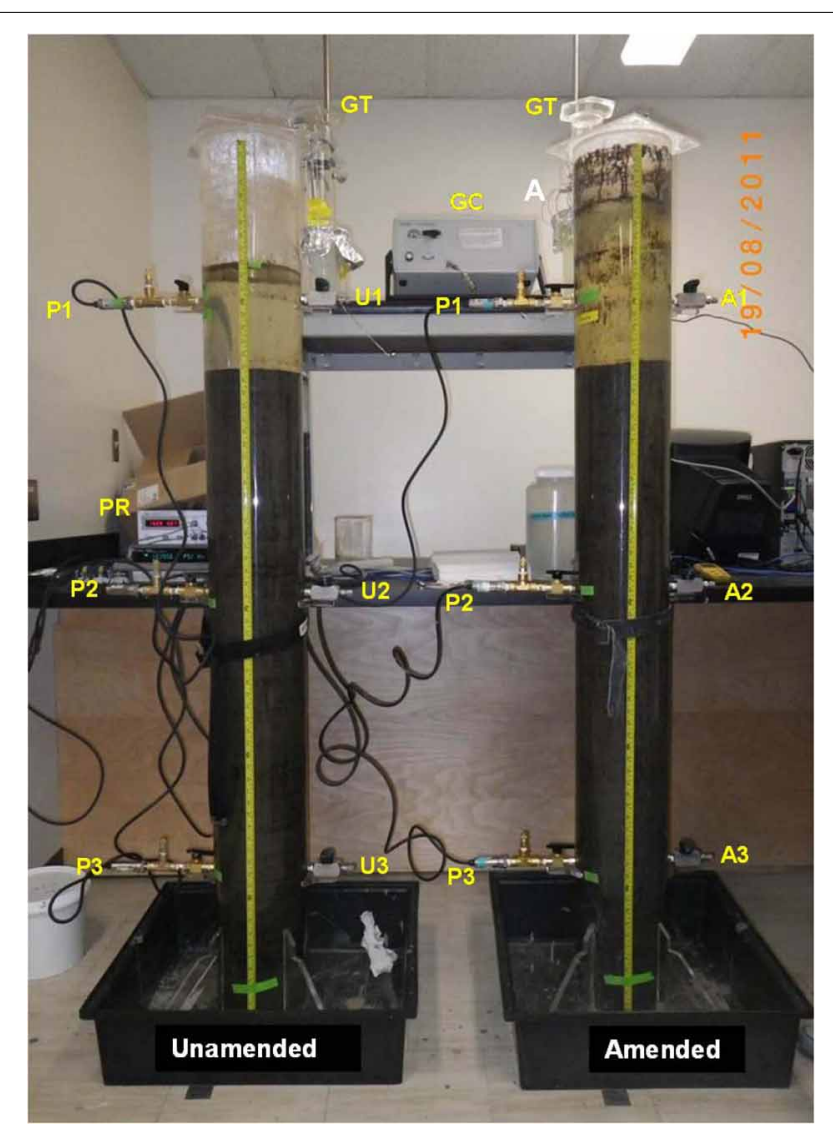

FIGURE 1 | Experimental 50-L columns used for measuring consolidation, porewater recovery and gas release from oil sands mature fine tailings (MFT) either amended (A) with an organic carbon source or unamended (U). The photograph was taken after $105 \mathrm{~d}$ incubation at $\sim 20^{\circ} \mathrm{C}$. Three sampling ports for collecting MFT or cap water (A1-A3; U1-U3) and three instrumentation ports (P1-P3) fitted with pressure transducers and a pressure reading unit (PR) for recording in situ pore pressure were installed in each column; see Methods for details. The columns were sealed under a $\mathrm{N}_{2}$ gas atmosphere. Stainless steel tubing connected the headspace to a micro-gas chromatograph (GC) to determine the composition of released biogenic gas, and to gas traps (GT) for measuring cumulative emitted gas volumes. combined results and biogeochemical models are relevant for proposed reclamation strategies for oil sands tailings in uplands and end pit lakes.

In addition, the fundamental mechanisms reported here have broad implications for developing geotechnical models to predict behavior of organic-rich saturated soft sediments (i.e., contaminated harbors, and marine, lacustrine and estuarine sediments), predicting contaminant transport from sediments to overlying water, and assessing remedial strategies for containing contaminants through in situ sediment capping (Himmelheber et al., 2011).

\section{MATERIALS AND METHODS PREPARATION OF 50-L COLUMNS}

Mature fine tailings (MFT; Table 1) and cap water were collected from Mildred Lake Settling Basin (MLSB; $57^{\circ} 4^{\prime} 27^{\prime \prime} \mathrm{N}$, $111^{\circ} 38^{\prime} 19^{\prime \prime} \mathrm{W}$ UTM) at Syncrude Canada Ltd. in Fort McMurray, Alberta, Canada in April 2011, and stored at room temperature $\left(\sim 20^{\circ} \mathrm{C}, c a\right.$. tailings pond in situ temperature) for a few days before using for the experiment. The solids and bitumen contents of the MFT were determined using the Dean and Stark method (Dean and Stark, 1920) to be $\sim 35$ and $\sim 2.5 \%$, respectively. The solids content was adjusted to $25 \mathrm{wt} \%$ solids using tailings pond "cap water" immediately before beginning

Table 1 | Chemical characteristics of mature fine tailings used in $50-\mathbf{L}$ column experiment prior to amendment and incubation.

\begin{tabular}{|c|c|}
\hline Analysis (units); number of replicates & Value \\
\hline \multicolumn{2}{|l|}{ DEAN-STARK $(w t \%)^{a} ; n=1$} \\
\hline Bitumen & 1.5 \\
\hline Water & 74.9 \\
\hline Solids & 23.4 \\
\hline Total & 99.8 \\
\hline \multicolumn{2}{|l|}{ TEXTURE $(w t \%)^{b} ; n=1$} \\
\hline Clay $<2 \mu \mathrm{m}$ & 25.6 \\
\hline Silt 2-50 $\mu \mathrm{m}$ & 70.9 \\
\hline Fine sand $50-250 \mu \mathrm{m}$ & 3.5 \\
\hline Bulk $\mathrm{pH} ; n=2$ & $7.3 \pm 0.03$ \\
\hline $\mathrm{E}_{h}(\mathrm{mV}) ; n=3$ & $-2.0 \pm 16$ \\
\hline \multicolumn{2}{|l|}{ SOLUBLE CATIONS (mg L-1 POREWATER) } \\
\hline $\mathrm{Ca}^{2+} ; n=2$ & $18.1 \pm 1.1$ \\
\hline $\mathrm{Mg}^{2+} ; n=3$ & $8.6 \pm 1.2$ \\
\hline $\mathrm{K}^{+} ; n=2$ & $24.6 \pm 2.7$ \\
\hline $\mathrm{Na}^{+} ; n=2$ & $737.8 \pm 37.6$ \\
\hline \multicolumn{2}{|l|}{ SOLUBLE ANIONS (mg L'-1 POREWATER) } \\
\hline $\mathrm{SO}_{4}^{2-} ; n=2$ & $20.6 \pm 1.2$ \\
\hline $\mathrm{Cl}^{-} ; n=3$ & $606.0 \pm 21.0$ \\
\hline $\mathrm{HCO}_{3}^{2-} ; n=3$ & $1620 \pm 58.5$ \\
\hline $\mathrm{PO}_{4}^{2-} ; n=3$ & $B D L^{c}$ \\
\hline Carbonates $(w t \%)^{\mathrm{b}} ; n=2$ & $2.4 \pm 0.1$ \\
\hline
\end{tabular}

Mean values of replicates are shown \pm 1 standard deviation.

a (Dean and Stark, 1920).

${ }^{b}$ Calculated on oven dry weight basis.

${ }^{c} B D L$, below detection limit $\left(0.01 \mathrm{mg} \mathrm{L}^{-1}\right)$. 
the experiment, to allow this study to be compared to previous studies (Young et al., in preparation). For each of two parallel 50-L columns (described below), $30 \mathrm{~L}$ MFT was combined with $15.45 \mathrm{~L}$ tailings pond cap water by gentle but thorough manual mixing under a curtain of $\mathrm{N}_{2}$ gas to achieve a solids content of $25 \mathrm{wt} \%$ while maintaining anaerobic conditions. For the test column, the added cap water contained soluble canola meal hydrolysate (preparation and composition described in Table 2) sufficient to provide a final concentration of $400 \mathrm{mg}$ $\mathrm{C} \mathrm{L}^{-1}$ MFT. The cap water used for adjusting MFT in the other column was unaltered, serving as a baseline control in which only endogenous carbon was available to support microbial activity.

Two cylindrical acrylic columns $(30.48 \mathrm{~cm}$ outer diameter, $0.64 \mathrm{~cm}$ wall thickness, and $195.6 \mathrm{~cm}$ height; Johnston Industrial Plastics Ltd., Edmonton, AB, Canada) were sealed at the base with acrylic plates and lateral supports (Figure 1). The cylinders were equipped with brass sampling ports (U1-U3 for unamended and A1-A3 for amended columns) for removal of MFT or water samples from the inner portion of the column, and with PX409005G5V (OMEGADYNE Inc.) pressure transducers (P1-P3) and an Agilent 34972A Data Acquisition/Data Logger pressure reading unit (PR) for measuring pore pressure in situ.

Table 2 | Elemental composition of hydrolyzed canola meal ${ }^{\mathrm{a}}$ used as the labile organic amendment in the experiment.

\begin{tabular}{lr}
\hline Analysis (units); number of replicates & Value \\
\hline ELEMENTAL ANALYSIS $\left(\mathbf{m g ~ g}^{-\mathbf{1}} \mathbf{)} \mathbf{b} ; \boldsymbol{n}=\mathbf{1}\right.$ & \\
Carbon & 28.1 \\
Nitrogen & 4.3 \\
Hydrogen & 4.0 \\
Sulfur & 0.4 \\
CATIONS (mg L-1) & \\
$\mathrm{Ca}^{2+} ; n=4$ & $1.6 \pm 0.1$ \\
$\mathrm{Mg}^{2+} ; n=4$ & $3.1 \pm 0.1$ \\
$\mathrm{~K}^{+} ; n=4$ & $15.7 \pm 0.2$ \\
$\mathrm{Na}^{+} ; n=4$ & $291.3 \pm 5.6$ \\
ANIONS (mg L$\left.^{-1}\right)^{\mathbf{c}}$ & \\
$\mathrm{SO}_{4}^{2-} ; n=2$ & $2.3 \pm 0.1$ \\
$\mathrm{Cl}^{-} ; n=2$ & $366.9 \pm 11.2$ \\
$\mathrm{HCO}_{3}^{2-} ; n=2$ & $213.3 \pm 8.9$ \\
$\mathrm{PO}_{4}^{2-} ; n=2$ & $0.9 \pm 0.04$ \\
\hline
\end{tabular}

Mean values of replicates are shown \pm 1 standard deviation.

${ }^{a}$ Canola hydrolysate was prepared from dry canola meal (post-pressing to remove oil; provided by Sanimax, Canada) by homogenizing the meal in a mortar and adding $10 \mathrm{~g}$ of powder to $90 \mathrm{ml}$ of $4 \%$ sodium hydroxide. The slurry was preheated to $60^{\circ} \mathrm{C}$ for $5 \mathrm{~min}$ and then stirred at $180 \mathrm{rpm}$ for $24 \mathrm{~h}$ at $60^{\circ} \mathrm{C}$. Following hydrolysis, the residue was collected by centrifugation at $9000 \mathrm{~g}$ and the supernatant was collected and adjusted to $\mathrm{pH} 9$ with drops of $1 \mathrm{M} \mathrm{HCl}$. The resulting liquid was freeze-dried and stored as a powder at room temperature.

${ }^{b}$ Calculated on oven dry weight basis.

${ }^{c}$ To assess the contribution of the canola meal amendment to soluble cations and anions in MFT porewater and cap water, the hydrolysate was dissolved in nanopure water at the same ratio as that used in the amended MFT (400 $\mathrm{mg} \mathrm{CL}^{-1}$ ).
The experiment was established on May 6, 2011 by filling each column with $45 \mathrm{~L}$ prepared MFT under a plastic curtain flushed with a continuous stream of nitrogen $\left(\mathrm{N}_{2}\right)$ to maintain anaerobic conditions and minimize exposure of MFT to air. In both columns, the adjusted MFT formed a single layer of suspended clays with no free water at the surface. After filling, the columns were sealed under an $\mathrm{N}_{2}$ headspace using acrylic plates fitted with gas-tight stainless steel gas ports and tubing $(0.15 \mathrm{~cm}$ diam.) connecting the headspace to a gas trap and a micro-gas chromatograph to determine the volume and composition of emitted gas, respectively. The columns were incubated in dim natural light at $\sim 20^{\circ} \mathrm{C}$. Real time measurements of biogenic gas production and composition, in situ $\mathrm{pH}$, porewater recovery and consolidation of tailings were recorded during $213 \mathrm{~d}$ incubation. Consolidation and porewater recovery were measured as the height of the cap water-solid interface (the "mud line") and corrected for trapped gas volume as described below.

At the end of the experiment, cap water and MFT samples were collected from the center of the column via sampling ports, using $4 \mathrm{~mm}$ stainless steel tubing and syringes. Samples were analyzed for carbonate minerals, soluble and exchangeable cations, and soluble anions, as described below. These samples were also subjected to solid phase chemical and molecular microbiological analyses described and discussed in the companion manuscript (Siddique et al., 2014).

We were unable to include sterilized MFT as a control condition for several reasons. First, we have observed previously (unpublished results) that it is very difficult to ensure sterilization of the thick MFT suspension, even with lengthy, repeated autoclaving over three or four successive days. Second, we did not wish to alter the structure or chemistry of the tailings by subjecting them to heat, as this could affect consolidation. Finally, we did not have access to a gamma source of sufficient capacity for irradiative sterilization of $\sim 90 \mathrm{~L}$ of MFT.

\section{SMALL-VOLUME COMPLEMENTARY EXPERIMENTS}

To observe the effect of non-biogenic (exogenous) gas amendment on consolidation of MFT, four parallel 2-L columns were prepared. Each column was filled with $1.7 \mathrm{~L}$ MFT (adjusted to $25 \%$ solids) under anaerobic conditions. One column received MFT that had been sparged with $\mathrm{N}_{2}$ gas (5.0 Ultra high purity, Praxair) at a flow rate of $62.5 \mathrm{~mL} \mathrm{~min}^{-1}$ for $1 \mathrm{~h}$ prior to dispensing into the column. MFT for two replicate columns was sparged with $\mathrm{CO}_{2}$ (4.0 Anaerobic, Praxair) at a flow rate of $72 \mathrm{~mL} \mathrm{~min}^{-1}$ for $1 \mathrm{~h}$ until $\mathrm{pH}$ stabilized between 6.54 and 6.68 , then was placed in the columns. MFT for the fourth column did not receive any gas sparging (untreated control). All columns were sealed under an anaerobic $\left(\mathrm{N}_{2}\right)$ headspace and incubated undisturbed at $\sim 20^{\circ} \mathrm{C}$ in the dark for $120 \mathrm{~d}$. The columns were monitored regularly for expressed porewater recovery (cap water) and solids consolidation by measuring the height of the mud line and water surface and converting to volume.

To test the effect of different cations, ionic strength and $\mathrm{pH}$ on the settling behavior of clays particles separately from microbial effects, a small-volume, short-term experiment was conducted in triplicate in $15-\mathrm{mL}$ conical Falcon tubes (Fisher Scientific, Canada). Seven milliliters of MFT was placed in each Falcon 
tube and amended with $7 \mathrm{~mL}$ of one of the following solutions: $1 \mathrm{~N} \mathrm{NaCl} ; 1 \mathrm{~N} \mathrm{CaCl}_{2} ; 1 \mathrm{~N} \mathrm{FeCl}_{2} ; 0.2 \mathrm{M}$ ammonium oxalate buffer (pH 3); 6M HCl (pH 1); or Nanopure water (Barnstead; Thermo Scientific). The tubes were shaken on a reciprocating shaker for $2 \mathrm{~h}$ and then placed upright on the bench to consolidate without disturbance. The mud line height in each tube was recorded after $30 \mathrm{~min}$ and again after $24 \mathrm{~h}$.

\section{ANALYTICAL METHODS AND CALCULATIONS}

We define here two water compartments analyzed in our experiments: (1) "porewater" is interstitial water associated with the colloidal MFT suspension, and is a component of the MFT; (2) "cap water" is porewater that has been expressed from the MFT and has collected above the mud line during consolidation. The term "mud line" used here is defined as the interface between cap water and MFT.

\section{Porewater recovery as cap water, and MFT consolidation}

The height of the mud line was used to measure solids consolidation and calculate porewater recovery. The volumes of cap water $\left(\mathrm{V}_{\mathrm{cw}}\right)$ and MFT (solids plus porewater plus gas below the mud line; $\mathrm{V}_{\mathrm{MFT}}$ ) were determined, respectively, by measuring the height of the cap water level above the mud line and height of the mud line in each column. The measured heights were converted to volumes using the following equation:

$$
\mathrm{V}=\pi r^{2} h_{\text {mud line }}
$$

where, $\mathrm{V}=$ volume of cap water or MFT,

$\mathrm{r}=$ inner radius of the column,

$\mathrm{h}_{\text {mud line }}=$ height of the cap water level or mud line.

Then, water recovery (WR) defined as the cap water volume (above the mud line) was calculated as a percentage of the initial volume of porewater in MFT:

$$
\mathrm{WR}=\left(\mathrm{V}_{\mathrm{cW}} / \mathrm{V}_{\mathrm{in}}\right) \times 100
$$

where, $\mathrm{WR}=$ water recovery $(\%)$,

$\mathrm{V}_{\mathrm{cw}}=$ measured volume of cap water,

$\mathrm{V}_{\text {in }}=$ initial volume of porewater MFT.

Consolidation of MFT is defined as the MFT volume (below the mud line) calculated as a percentage of the initial volume of MFT

$$
\text { Consolidation }(\%)=\left[\left(\mathrm{V}_{\text {in }}-\mathrm{V}_{\mathrm{MFT}}\right) / \mathrm{V}_{\text {in }}\right] \times 100
$$

where, $\mathrm{V}_{\mathrm{MFT}}=$ measured volume of $\mathrm{MFT}$ and $\mathrm{V}_{\text {in }}=$ initial volume of MFT.

\section{Estimation of MFT consolidation in 50-L columns by deducting volume of entrapped gas bubbles}

Estimated consolidation of MFT in unamended and amended columns was calculated using the following equation:

$$
\text { Consolidation }(\%)=\left[\left(\mathrm{V}_{\text {in }}-\mathrm{V}_{\mathrm{MFT}-\mathrm{d}}\right) / \mathrm{V}_{\mathrm{in}}\right] \times 100
$$

where, $V_{\text {in }}$ is the initial volume of MFT $(45 \mathrm{~L})$, and $V_{\text {MFT-d }}$ is volume of MFT without gas at different densities that are calculated as:

$$
\mathrm{V}_{\text {MFT-d }}=\left(\mathrm{m}_{\text {MFT-In }}-\mathrm{m}_{\mathrm{wr}}\right) / \mathrm{D}
$$

where, $\mathrm{m}_{\text {MFT-In }}$ is the initial mass of MFT $(54.9 \mathrm{~kg}) ; \mathrm{m}_{\mathrm{wr}}$ is the mass of released water. D is the density of the MFT on different days, determined from the mean weight of five replicate $10-\mathrm{mL}$ subsamples of MFT.

\section{Volume and composition of gas emitted by ebullition}

The volume of gas emitted from 50-L columns was measured using a NaCl-citric acid brine gas trap (Boone, 1982). The composition of produced gas for $\mathrm{CH}_{4}$ and $\mathrm{CO}_{2}$ was determined using a Varian CP-2003 portable Micro-GC (gas chromatograph) equipped with a GMT-2HP moisture trap and thermal conductivity detector (TCD). The minimum detection limit of this GC was $50 \mathrm{ppm}$.

\section{$p H$ and redox potential $\left(E_{h}\right)$}

The $\mathrm{pH}$ was determined in situ at intervals during incubation by inserting a $\mathrm{pH}$ meter (Hach H170multi) fitted with an ISFET $\mathrm{pH}$ stainless steel micro probe (PHW17-SS) through side ports (Figure 1). For $\mathrm{E}_{\mathrm{h}}$ measurements, MFT samples were collected from ports 2 and 3 under a continuous flow of $\mathrm{N}_{2}$ and immediately subjected to $\mathrm{E}_{\mathrm{h}}$ measurement using a TX100 pH/mV-meter fitted with redox-sensitive electrode (Sensorex 651CD-ORP).

\section{Soluble cations and anions}

MFT samples removed from the columns were centrifuged (3075 $\mathrm{g}$ for $1 \mathrm{~h}$ ) in a Sorvall RC 5B Superspeed centrifuge to collect the porewater. The solids fraction was analyzed as described below. For the soluble cations calcium $\left(\mathrm{Ca}^{2+}\right)$, magnesium $\left(\mathrm{Mg}^{2+}\right)$, sodium $\left(\mathrm{Na}^{+}\right)$and potassium $\left(\mathrm{K}^{+}\right)$, porewater was filtered and diluted with $1 \% \mathrm{HNO}_{3}$ (trace metal grade) and analyzed using Inductively Coupled Plasma Mass Spectrometry (ICP-MS; Perkin Elmer SCIEX ELAN 9000) with appropriate internal and external standards. Chloride $\left(\mathrm{Cl}^{-}\right)$, nitrate $\left(\mathrm{NO}_{3}^{-}\right)$ and sulfate $\left(\mathrm{SO}_{4}^{2-}\right)$ soluble anion concentrations were determined using an ion chromatograph (Dionex DX 600) equipped with a $4 \mathrm{~mm}$ analytical column (AS9-HC). Dissolved bicarbonates $\left(\mathrm{HCO}_{3}^{-}\right)$were determined using the methyl orange indicator method (US EPA, 1974) and Smartchem Discrete Wet Chemistry Analyzer 200 (Westco Scientific) at $550 \mathrm{~nm}$. The $\mathrm{PO}_{4}^{3-}$ concentration was determined using the colorimetric Molybdenum Blue method (US EPA, 1993) using the SmartChem at $\lambda 880 \mathrm{~nm}$.

\section{Moisture correction factor}

Data from chemical analyses of the solid phase (carbonates and exchangeable cations) were corrected for moisture and expressed on a solid dry weight basis. Moisture content in the samples was determined by drying in an oven at $105^{\circ} \mathrm{C}$ to constant weight (ISO 11465, 1993). The moisture content was obtained in weight percent and the corresponding correction factor was developed using the following equation:

Moisture correction factor $(\mathrm{MCF})=(100+$ moisture $\%) / 100$ 


\section{Exchangeable cations}

Five grams of MFT were collected in 50-mL polypropylene centrifuge tubes (Corning Inc.) and $20 \mathrm{~mL}$ of $0.1 \mathrm{M} \mathrm{BaCl}_{2} / 0.1 \mathrm{M}$ $\mathrm{NH}_{4} \mathrm{Cl}$ solution was added to displace the exchangeable cations (Sparks, 1996; Carter and Gregorich, 2008; Rayment and Lyons, 2012). The samples were shaken for $2 \mathrm{~h}$ and centrifuged $(3075 \mathrm{~g}$ for $1 \mathrm{~h}$ ) in a Sorvall RC 5B Superspeed centrifuge. The supernatant was diluted with $1 \% \mathrm{HNO}_{3}$ (trace metal grade) and analyzed using ICP-MS. In a few cases where the samples were not analyzed immediately after centrifugation, the supernatant was preserved by acidification to $\mathrm{pH}$ 1-2 using $\mathrm{HNO}_{3}$. The concentrations of exchangeable cations were calculated by subtracting concentrations of soluble cations (So et al., 2006). The results were expressed on dry weight basis.

\section{Ionic Strength (I) and Diffuse Double Layer (DDL)}

Ionic strength of the MFT porewater was calculated using the following formula (Essington, 2004):

$$
\mathrm{I}=1 / 2 \sum_{i}\left(\mathrm{M}_{i} \mathrm{Z}_{i}^{2}\right)
$$

where, $M_{i}$ is the molar concentration of charged species ( $i$ ) with charge $Z_{i}$ in the porewater and the sum includes all charged species measured in the porewater.

The thickness of the DDL was calculated using the following formula (Essington, 2004):

$$
\mathrm{k}^{-1}=\left(3.042 \times 10^{-8}\right) / \mathrm{ZI} I^{0.5}
$$

where, $\mathrm{k}^{-1}$ is the thickness $(\mathrm{cm})$ of the DDL, $\mathrm{Z}$ is the average mean charge of the counterions (exchangeable cations), and $I$ is the ionic strength of the porewater. Because MFT is a polyionic system having ions of different charges, the average mean charge of the exchangeable cations was calculated using the following equation:

$$
\mathrm{Z}_{\mathrm{ave}}=\sum \mathrm{C}_{i} \mathrm{Z}_{i} / \sum \mathrm{C}_{i}
$$

where, $\mathrm{C}_{i}$ is the concentration of ions on the exchangeable surface and $Z_{i}$ is the charge of the species $(i)$.

\section{Carbonate minerals}

The total carbonates in the MFT solid phase were determined by acid digestion (Pansu and Gautheyrou, 2006). The MFT $(\sim 10 \mathrm{~mL})$ was centrifuged to separate the solid phase which was washed twice with $30 \mathrm{~mL}$ methanol to remove any soluble $\mathrm{HCO}_{3}^{-}$. The MFT solid phase ( $\sim 2 \mathrm{~g}$ ) was placed in a serum bottle capped with a butyl rubber stopper and the headspace in the bottle was flushed with $\mathrm{N}_{2}$ at atmospheric pressure. The carbonates were dissolved by adding $20 \mathrm{~mL}$ of $1 \mathrm{M} \mathrm{HCl}$ to the bottles using a syringe. The bottle was gently shaken for $2 \mathrm{~h}$ and the amount of $\mathrm{CO}_{2}$ released was measured using GC-TCD (HP 5890). After $\mathrm{CO}_{2}$ measurement, the contents of the bottle were analyzed for $\mathrm{Ca}$ and $\mathrm{Mg}$ using an Atomic Absorption Spectrometer (AAS; SpectrAA $880)$. These concentrations were used to calculate $\mathrm{CaCO}_{3}$ and $\mathrm{CaMg}\left(\mathrm{CO}_{3}\right)_{2}$ in the MFT.

\section{RESULTS}

We investigated contributions of microbial activity (methanogenesis) to consolidation in a series of experiments conducted at different scales from $2-\mathrm{L}$ to $50-\mathrm{L}$ column studies. The results reveal that methanogenesis is important for rapid consolidation of MFT, an effect that is superimposed on tailings self-weight consolidation. Acetate, a well-known substrate for methanogenesis, resulted in greater porewater recovery and solids consolidation when added to MFT as compared to unamended MFT (Figure 2; constructed using data retrieved from Bressler et al., 2010). The same phenomenon has also been observed in our previous experiments (Arkell et al., in review; Young et al., in preparation). The increase in total volume in the acetate-amended MFT shown in Figure 2A, left panel is due to biogas entrained in the MFT solids. However, specifically inhibiting methanogenesis by adding sodium 2-bromoethanesulfonate (BES) resulted in minimal consolidation, presumably equivalent to self-weight settling, minimal porewater recovery and no visible pockets of entrained gas (Figure 2). Thus, it appears that active methanogenesis is a prerequisite for biodensification of MFT incubated under these conditions.

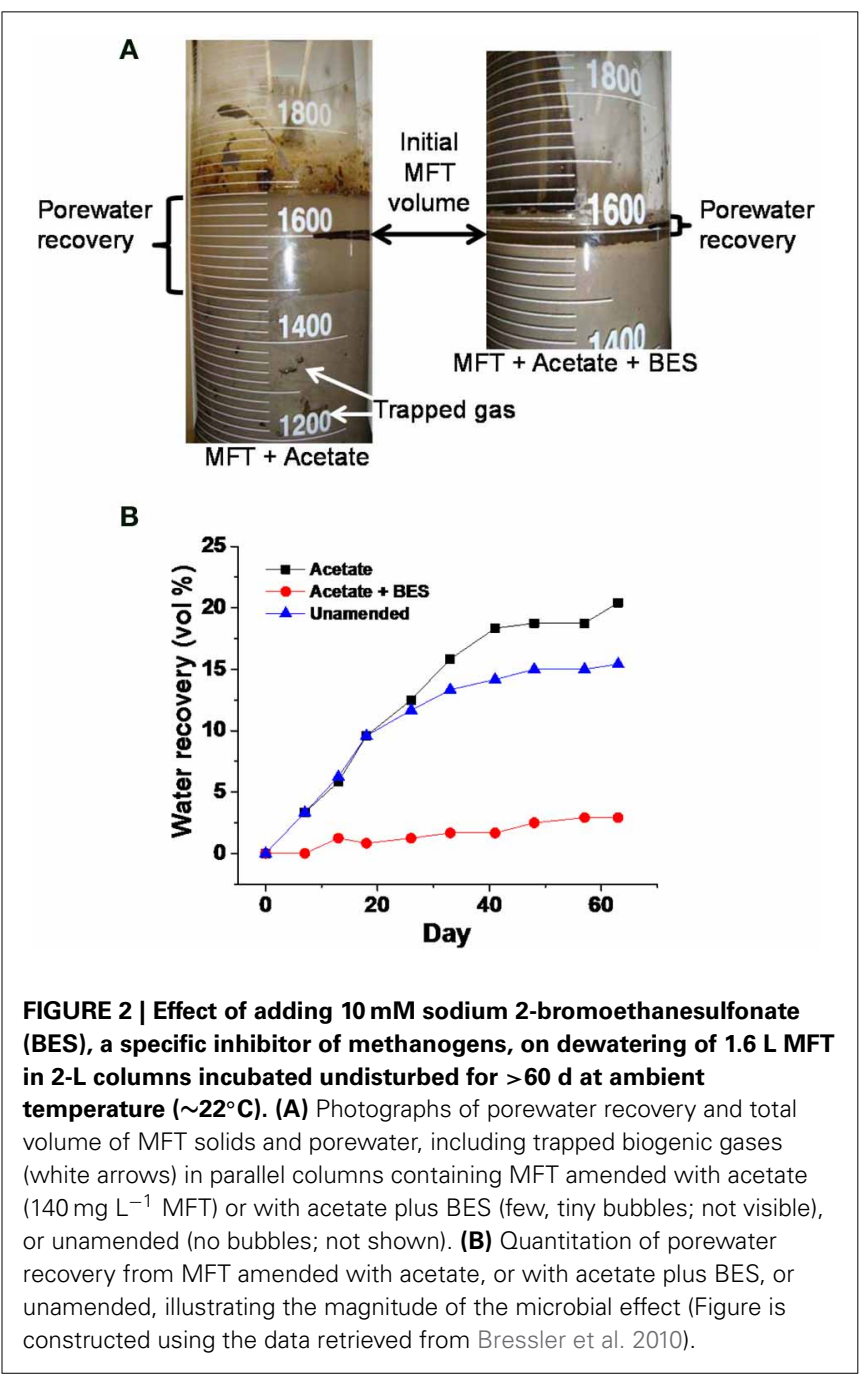


To further demonstrate the contribution of biogenic vs. abiotic gases to porewater recovery and consolidation, small-scale (2-L column) experiments were performed in which unamended MFT was sparged with $\mathrm{CO}_{2}$ to simulate biogenic $\mathrm{CO}_{2}$ production, or with $\mathrm{N}_{2}$ gas to simulate the effect of insoluble gas ebullition (by creating transient physical channels for expression of porewater). Only marginal differences in porewater recovery and tailings consolidation were observed compared to nonsparged MFT (Figure 3). The small proportion and slow rates of consolidation and porewater recovery (compared to acetateamended MFT; Figure 2) presumably are due to methanogenic activity supported by endogenous organic substrates in MFT.

\section{BIOGENIC GAS PRODUCTION AND DECREASED pH AFFECT POREWATER RECOVERY FROM MFT IN 50-L COLUMNS}

In previous small-volume experiments we used complex or simple fermentable organic amendments to accelerate dewatering and consolidation of MFT (Bressler et al., 2010; Arkell et al., in review; Young et al., in preparation), and determined

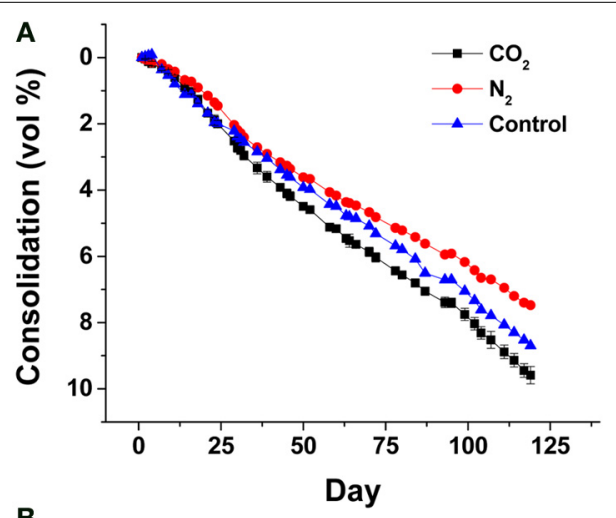

B

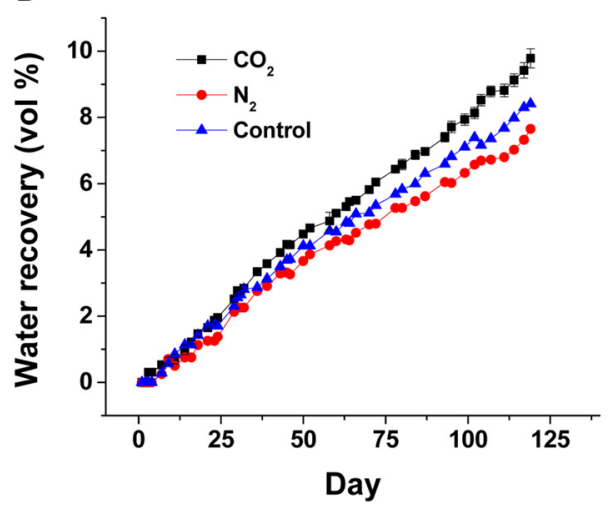

FIGURE 3 | Effect of abiotic gas purging on MFT consolidation (A) and porewater recovery (B). Four replicate $2-\mathrm{L}$ columns containing $1.7 \mathrm{~L}$ unamended MFT were purged with $\mathrm{CO}_{2}(n=2$; error bars, where visible, show the standard error) or $\mathrm{N}_{2}(n=1)$ or no gas purging $(n=1)$ prior to dispensing MFT into columns. Consolidation was calculated from the volume of solids below the mud line as a fraction of the total volume of MFT plus water plus any trapped gas. Porewater recovery was calculated using the recovered porewater volume above the mud line (i.e., cap water volume) as a fraction of the initial total volume of porewater in MFT. that a low concentration of hydrolyzed canola meal $(400 \mathrm{mg}$ $\mathrm{C} \mathrm{L} \mathrm{L}^{-1} \mathrm{MFT}$ ) was sufficient to promote tailings biodensification under methanogenic conditions. In the current experiment, it is apparent that methanogenic conditions were established in the 50- $\mathrm{L}$ columns, as anaerobic metabolism of the soluble canola hydrolysate resulted in emission of $\sim 2.8 \mathrm{~L} \mathrm{CH}_{4}$ and $\sim 0.5 \mathrm{~L}$ $\mathrm{CO}_{2}\left(\mathrm{CH}_{4}: \mathrm{CO}_{2}\right.$ ratio of 5.6:1) to the headspace by $75 \mathrm{~d}$, with minor gas production from unamended MFT (Figure 4A). Additional biogenic gas was trapped within amended MFT (Figure S1 Panel B), contributing to the total apparent volume of MFT. Stoichiometric calculation of theoretical gas production from canola, based on the Symons and Buswell equation (Roberts, 2002), predicted a $\mathrm{CH}_{4}: \mathrm{CO}_{2}$ ratio of $\sim 3: 1$, but substantially less $\mathrm{CO}_{2}$ than predicted was measured in the headspace (Figure 4A). The deficit in emitted $\mathrm{CO}_{2}$ is explained by dissolution of biogenic $\mathrm{CO}_{2}$ in porewater, which decreased the $\mathrm{pH}$ of amended MFT from 7.7 to 6.4 by $147 \mathrm{~d}$, whereas the $\mathrm{pH}$ of unamended MFT was essentially unchanged in $>200 \mathrm{~d}$ (Figure 4B). We initially observed an increase in $\mathrm{pH}$ in the amended MFT during the first $35 \mathrm{~d}$, after which it significantly decreased. During active gas biogenesis in the first 2 months, $12 \%$ more porewater was released from amended MFT than unamended (Figure 4C), most of which coincided with $\mathrm{pH}$ reduction, a major ebullition event at $50 \mathrm{~d}$, and rapid consolidation of amended MFT. Ebullition of biogenic $\mathrm{CH}_{4}$ created transient channels for escape of porewater from MFT, observed particularly near the mud line (MFT-cap water interface; Figure S1). Other experiments (unpublished) confirmed that transient water- and gas-filled channels can form in MFT to allow passage of porewater to the surface during this phase. Gas bubbles remaining in the amended MFT did not affect subsequent consolidation behavior (Figure S2), but did contribute to the apparent total solids volume; complete degassing theoretically would have yielded $\sim 15$ vol\% more consolidation in the amended column (Figure 4D).

\section{pH AFFECTS DISSOLUTION OF CARBONATE MINERALS AND POREWATER CHEMISTRY}

The decreased $\mathrm{pH}$ in amended MFT due to dissolution of biogenic $\mathrm{CO}_{2}$ increased dissolution of carbonate minerals in MFT (Figure 5A): at $213 \mathrm{~d}$, the carbonate mineral content in amended MFT $(1.7 \mathrm{wt} \%)$ was significantly lower than unamended MFT (2.7 wt \%). Carbonate dissolution increased soluble cation concentrations in porewater and cap water: $\mathrm{Ca}^{2+}$ and $\mathrm{Mg}^{2+}$ concentrations were greater in amended MFT $(\sim 32$ and $19 \mathrm{mg} \mathrm{L}^{-1}$, respectively) than unamended MFT $(\sim 17$ and $10 \mathrm{mg} \mathrm{L} \mathrm{L}^{-1}$, respectively; Figure $\left.5 \mathrm{~B}\right)$. In contrast, soluble $\mathrm{K}^{+}$ decreased in amended MFT (Figure 5B) whereas the soluble $\mathrm{Na}^{+}$concentration remained unaffected in amended MFT porewater (Figure 5C). A very small concentration of soluble phosphate $\left(\mathrm{PO}_{4}^{3-}\right)$ was detected only in amended MFT porewater $\left(0.36 \mathrm{mg} \mathrm{L}^{-1}\right)$ with low concentrations of sulfate $\left(\mathrm{SO}_{4}^{2-},<5 \mathrm{mg} \mathrm{L}^{-1}\right)$ (Figure 5D). Amended MFT had slightly higher porewater concentrations of soluble $\mathrm{HCO}_{3}^{-}(\sim 1500 \mathrm{mg}$ $\left.\mathrm{L}^{-1}\right)$ than unamended MFT $\left(\sim 1380 \mathrm{mg} \mathrm{L}^{-1}\right)$ but $\mathrm{Cl}^{-}$concentrations were comparable in both amended and unamended MFTs (Figure 5E). 

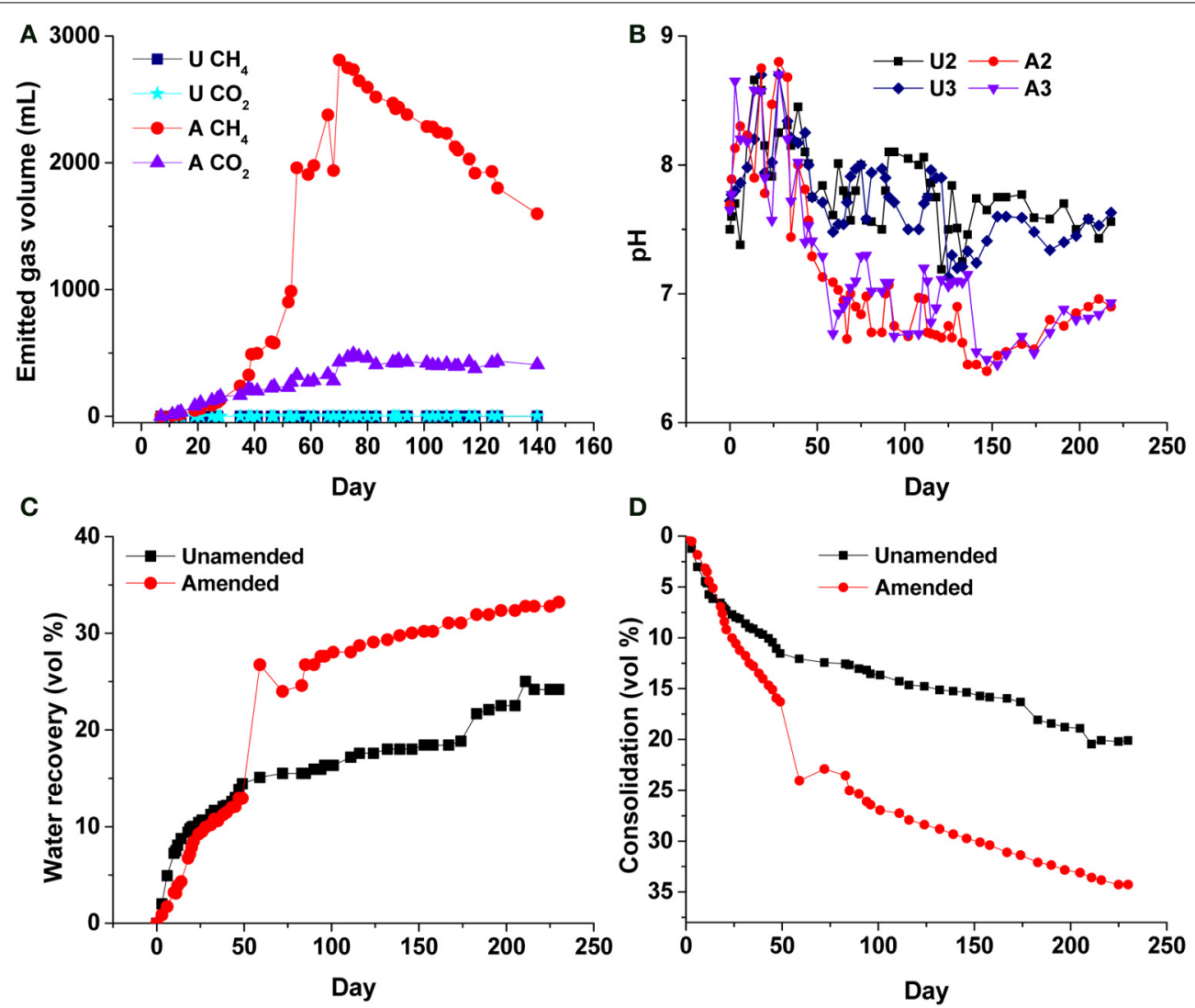

FIGURE 4 | Physico-chemical changes to unamended (U) and amended (A) MFT in 50-L columns. (A) Cumulative emitted methane $\left(\mathrm{CH}_{4}\right)$ and carbon dioxide $\left(\mathrm{CO}_{2}\right)$ in headspace (not accounting for gases trapped or dissolved in MFT); (B) bulk pH of MFT, measured at ports 2 and 3; (C)

Proportion of initial porewater recovered above the mud line as cap water (i.e., expressed porewater). The sudden increase in cap water in the amended column corresponded to a large ebullition event at $\sim 50$ days recorded in $\mathbf{A}$; (D) Consolidation of solids, corrected for trapped gas volumes by subtracting the estimated volume of trapped gas from the measured total MFT volume. Initial and final densities of unamended $(D=1.22$ and $1.30 \mathrm{~g}$ $\mathrm{mL}^{-1}$, respectively) and amended MFT $\left(D=1.22\right.$ and $1.49 \mathrm{~g} \mathrm{~mL}^{-1}$, respectively) were used to calculate consolidation; see Methods for details.

\section{EXCHANGEABLE CATIONS, IONIC STRENGTH AND DIFFUSE DOUBLE LAYER (DDL)}

Although dissolution of carbonates increased $\mathrm{Ca}^{2+}$ and $\mathrm{Mg}^{2+}$ concentrations in porewater of amended MFT, no significant change in the composition of exchangeable cations on clay surfaces was observed in MFT (Figure 5F). However, increased concentrations of soluble cations $\left(\mathrm{Ca}^{2+}\right.$ and $\left.\mathrm{Mg}^{2+}\right)$ and anions $\left(\mathrm{HCO}_{3}^{-}\right)$increased the ionic strength $(I)$ of the porewater (Figure 6A). The greater $I\left(\sim 0.055 \mathrm{~mol} \mathrm{~L}^{-1}\right)$ was calculated for the porewater from amended MFT vs. unamended MFT $\left(\sim 0.04 \mathrm{~mol} \mathrm{~L}{ }^{-1}\right)$. The $I$ of a solution has a profound effect on the DDL of clay particles. Increased $I$ in the porewater of amended MFT decreased the DDL thickness $\left(\sim 10 \times 10^{-8} \mathrm{~cm}\right)$ of clay particles in amended MFT as compared to the DDL thickness $\left(\sim 18 \times 10^{-8} \mathrm{~cm}\right)$ calculated for clay particles in unamended MFT (Figure 6B).

\section{DISCUSSION}

Dewatering of tailings is a major challenge faced by the surface-mining oil sands industry to comply with government directives for managing the ever-growing inventory of oil sands tailings (http://www.aer.ca/rules-and-regulations/ directives/directive-074). Any process that increases the settling of clay particles in oil sands tailings ponds will enhance consolidation of tailings to reduce the inventory volume and enable reclamation, and will increase recovery of porewater from MFT for re-use and reduction of fresh water demand; even marginal increases in consolidation translate into enormous volumes, given the scale of existing tailings ponds $\left(>920\right.$ million $\left.\mathrm{m}^{3}\right)$. Thus, microbially-mediated consolidation and dewatering (biodensification) can mitigate this problem, whether supported by endogenous substrates in situ (Fedorak et al., 2003) or by amendment with organic substrates in an engineered process ex situ. In this paper, we have focused on how microbial activities alter porewater chemistry to enhance tailings consolidation and dewatering; in the companion paper (Siddique et al., 2014), we consider the effect on tailings solids.

The mechanism of microbially-mediated consolidation (biodensification) of oil sands tailings is multi-faceted, embracing different biogeochemical processes occurring simultaneously in the MFT (Figure 7). Stimulating the activity of indigenous anaerobes by amending MFT with labile organic carbon (hydrolyzed 

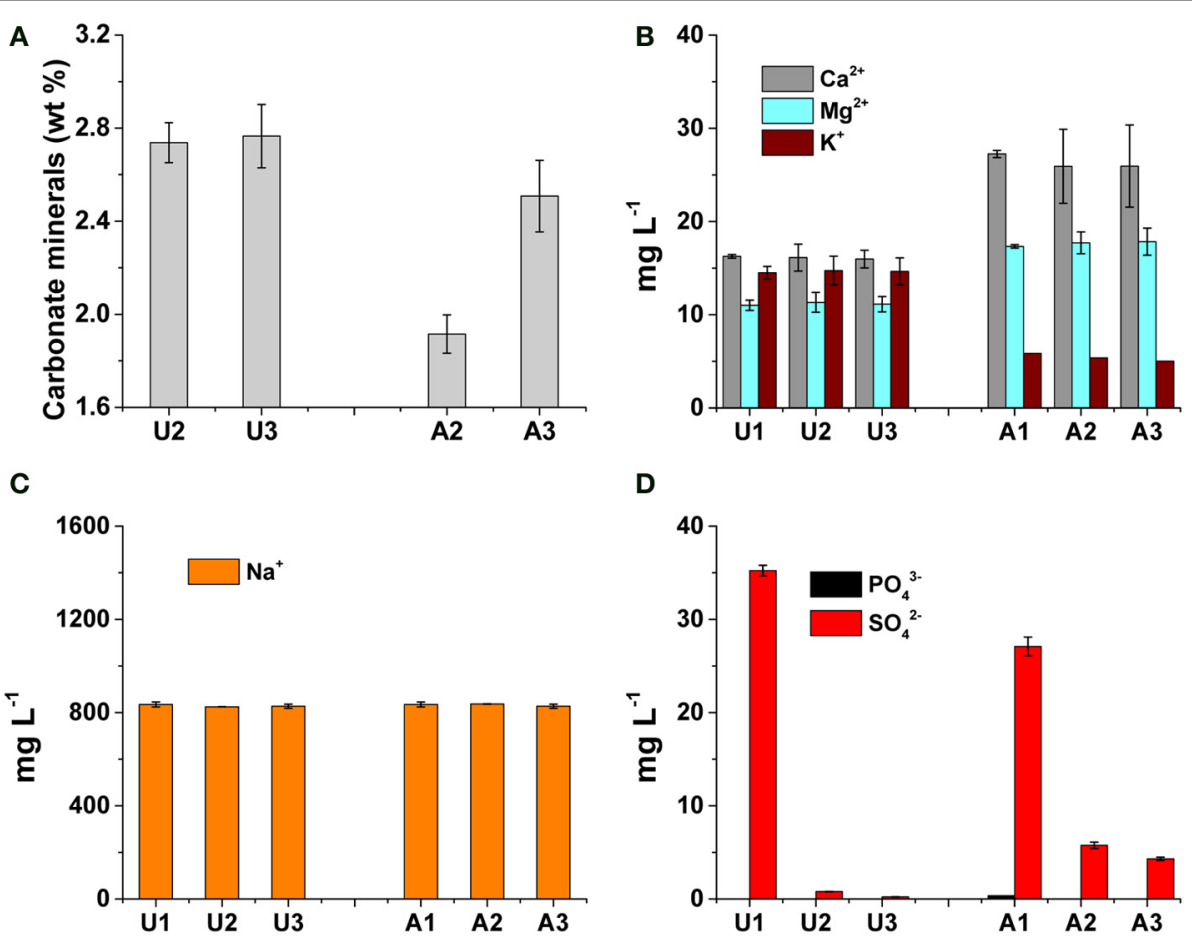

D
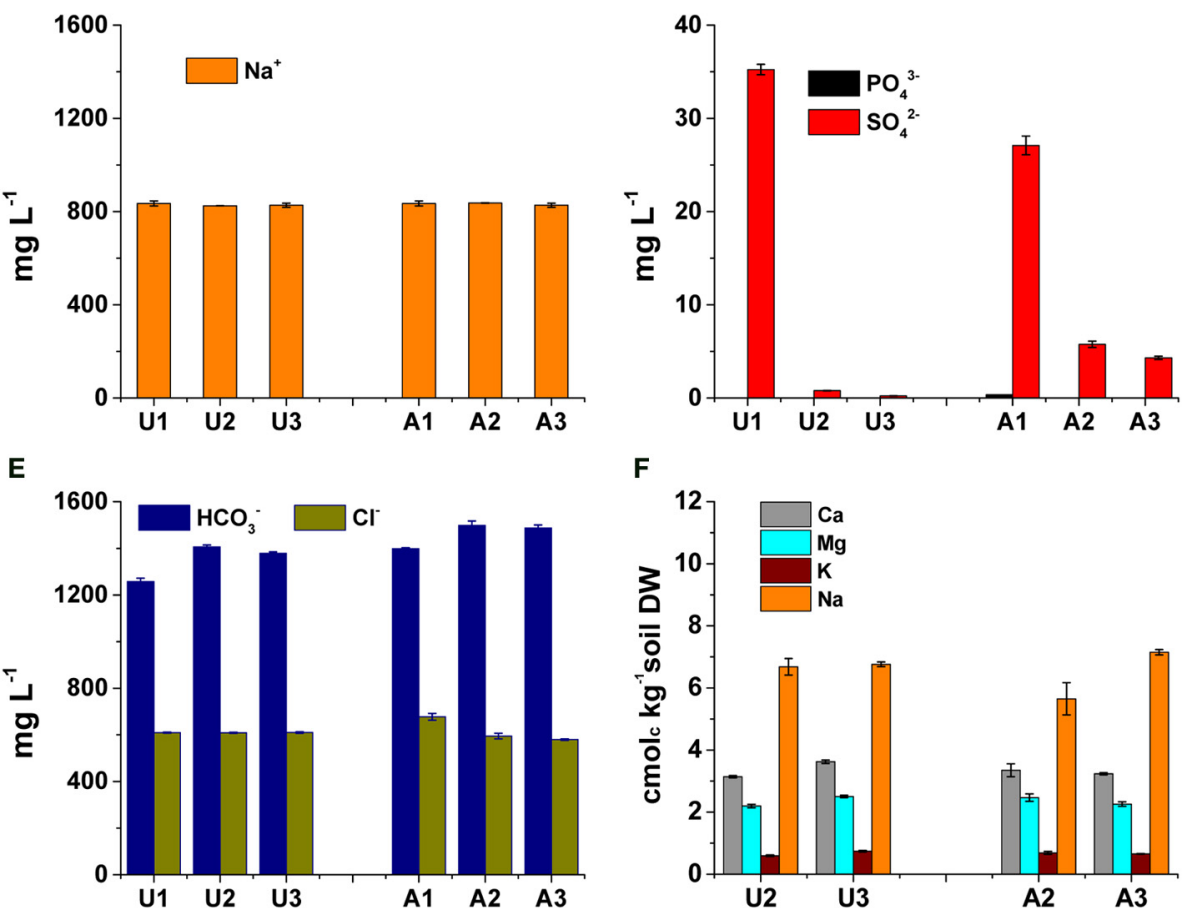

$\mathbf{F}$

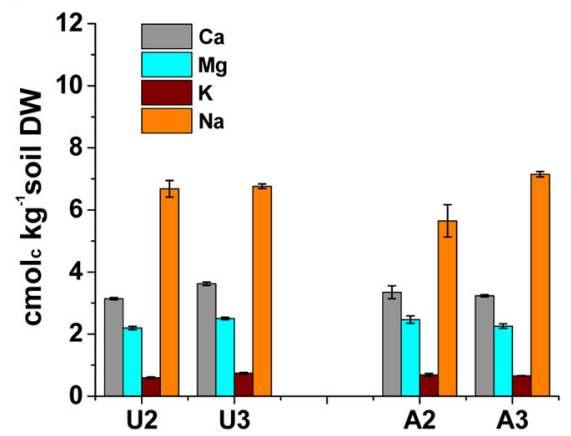

FIGURE 5 | Concentrations of carbonate minerals and major cations and anions in unamended (U) and amended (A) 50-L columns after $213 \mathbf{d}$ incubation. Labels 1,2 , and 3 refer to samples collected from ports on the columns (see Figure 1); Port 1 accessed cap water only by $213 \mathrm{~d}$; ports 2 and 3 were below the mud line and accessed MFT. Bars represent the mean from analyses of duplicate or triplicate samples

taken from each port and error bars, where visible, represent 1 standard deviation. (A) Carbonate mineral content of MFT samples $(n=3)$. (B,C) Concentrations of major soluble cations in cap water and interstitial porewater $(n=2)$. (D,E) Concentrations of major soluble anions in cap water and interstitial porewater $(n=2)$. (F) Concentrations of exchangeable cations in MFT $(n=2)$.

canola meal in this study, acetate in previous studies; Fedorak et al., 2003; Arkell et al., in review) enhanced biogenic $\mathrm{CH}_{4}$ and $\mathrm{CO}_{2}$ production. Gas production resulted in ebullition of bubbles dominated by $\mathrm{CH}_{4}$ (due to poor solubility of $\mathrm{CH}_{4}$ in water), creating transient channels for escape of pressurized porewater, particularly in MFT near the mud line. Methanogenesis in MFT might be responsible for the observed initial $\mathrm{pH}$ increase as acetate and $\mathrm{CO}_{2}$ were consumed (Fotidis et al., 2013) but the dissolution of entrapped $\mathrm{CO}_{2}$ reduced porewater $\mathrm{pH}$, thereby dissolving carbonate minerals and releasing divalent cations (Pathway I in Figure 7). Our results are very similar to the findings of Wersin et al. (2011) who studied biogeochemical processes in a clay formation in situ. They observed carbonate dissolution, high $\mathrm{pCO}_{2}$ and alkalinity $\left(\mathrm{HCO}_{3}^{-}\right.$and $\left.\mathrm{CO}_{3}^{2-}\right)$ and a decrease in $\mathrm{pH}$ from 7.7 to 6.8 during anaerobic degradation of an organic substrate under sulfate-reducing and methanogenic conditions. Similar results were also reported by Schlegel et al. (2011) studying fluid geochemistry and microbiology of multiple organic-rich reservoirs in the Illinois Basin, USA. Our results are also supported by other studies where the influence of benthic bacterial activity on carbonate mineral dissolution in marine sediments has been described (Moulin et al., 1985) and dissolution of marine carbonate minerals by acidification due to increased atmospheric $\mathrm{CO}_{2}$ has been comprehensively reviewed (Morse et al., 2007). Solubility of $\mathrm{CaCO}_{3}$ increases 20 -fold between $\mathrm{pH}$ 8 and pH 6 (Chou et al., 1989) and siderite can be dissolved 


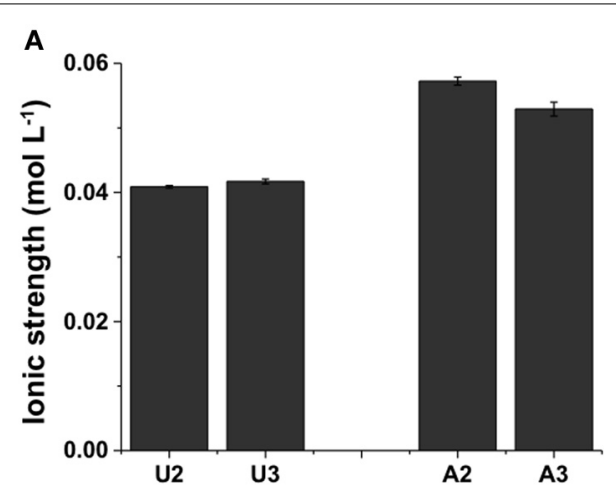

B

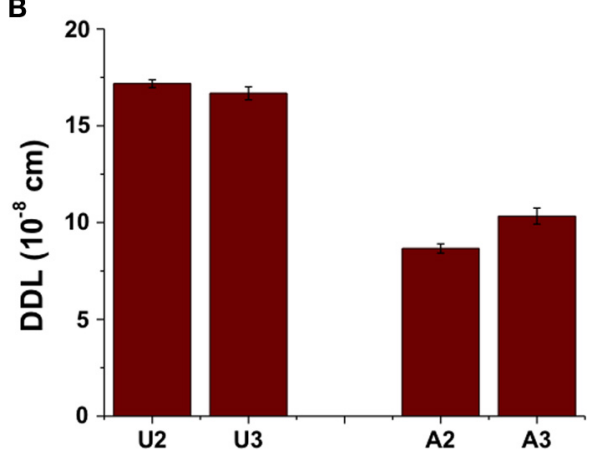

FIGURE 6 | (A) Calculated ionic strength (/) of the porewater and (B) thickness of diffuse double layer (DDL) of clay particles in unamended (U) and amended (A) MFT in the 50-L columns at ports 2 and 3 (Figure 1). Ionic strength was calculated using the data presented in Figure 5, the DDL thickness was calculated using the ionic strength, and charges of exchangeable cations were calculated from data shown in Figure 5F. Bars represent the mean values from analyses of duplicate samples taken from each port and error bars, where visible, represent 1 standard deviation.

in anaerobic aqueous environments at $\mathrm{pH} \sim 7$ (Jensen et al., 2002).

Dissolution of MFT carbonate minerals (presumably calcite/dolomite) increased $\mathrm{Ca}^{2+}$ and $\mathrm{Mg}^{2+}$ concentrations in amended porewater, whereas $\mathrm{K}^{+}$decreased in amended MFT, which might be attributed to reducing conditions prevailing in amended MFT (Siddique et al., 2014) facilitating $\mathrm{K}^{+}$fixation in reduced 2:1 phyllosilicates (Eslinger et al., 1979; Shen and Stucki, 1994). Phyllosilicate analysis of MFT showed that fine clay $(0.08-$ $0.2 \mu \mathrm{m}$ ) comprised $\sim 45 \%$ kaolinite-smectite (94\% kaolinite) and $55 \%$ illite-smectite (93\% illite) group minerals whereas clay (0.2$2 \mu \mathrm{m})$ consisted of $62 \%$ kaolinite-smectite (100\% kaolinite) and $36 \%$ illite-smectite (96\% illite) groups (Siddique et al., 2014). Among anions, a relatively higher concentration of $\mathrm{HCO}_{3}^{-}$in the porewater of amended MFT was observed, presumably due to dissolution of biogenic $\mathrm{CO}_{2}$ in porewater and/or dissolution of carbonate minerals (Morse et al., 2007). The change in porewater chemistry of amended MFT due to microbial metabolism did not alter the cationic composition on clay exchanger surfaces despite significant increases in divalent cation concentrations $\left(\mathrm{Ca}^{2+}\right.$ and $\left.\mathrm{Mg}^{2+}\right)$ in the porewater. However, the divalent cation concentrations were dwarfed by the $\mathrm{Na}^{+}$concentration, which dominated the porewater composition. Another possible reason for the apparent lack of cation exchange could be technical, since no method has been optimized yet to determine the exchangeable cations in oil sands tailings. Although we cannot exclude cation exchange processes based on our results, we do not consider cation exchange to be a significant or essential process in MFT consolidation (Pathway I, Figure 7, broken lines).

The phenomenon of clay dispersion in aqueous systems is understood using the concept of diffuse double layer (DDL), the thickness of which is governed by the charge potential on the clay surface (one electric layer, generally with net negative charge on clay surface) and valence of the counterions in solution (second electric layer, positive charge contributed by cations) neutralizing the surface charge potential of clay. Decreasing thickness of DDL increases clay flocculation. In our study, the greater ionic strength $(I)$ of porewater from amended MFT, attributed to increased concentrations of soluble ions $\left(\mathrm{Ca}^{2+}, \mathrm{Mg}^{2+}\right.$, and $\mathrm{HCO}_{3}^{-}$), would decrease the thickness of the DDL of clay particles (Figure 6) and enhance consolidation of tailings. Electrostatic repulsion between the clay particles is reduced at higher $I$ due to ion shielding of the clay surface charges, decreasing thickness of the DDL. Greater consolidation of amended MFT might also be attributed to dominance of kaolinite phyllosilicates in the MFT, in addition to greater $I$. The charges on kaolinite are largely $\mathrm{pH}$ dependent, and the observed lower $\mathrm{pH}$ of MFT would decrease the net negative charges on the clay surfaces. Nasser and James (2006) examined the settling behavior of kaolinite in aqueous media in response to $I$ and found that, at higher $I$, particles settled in flocculated form. Similar results were reported by Mietta et al. (2009) for flocculation of a kaolinite suspension as function of $\mathrm{pH}$ and salt concentration, and they found that clay floc size was 3 -fold greater at $\mathrm{pH} 4$ than at $\mathrm{pH} 7$. Our small-scale, short-term (24-h) abiotic experiment conducted with unamended MFT confirmed that adding different salts or decreasing bulk $\mathrm{pH}$ by adding acid markedly increased consolidation and porewater recovery from tailings (Figure S3). Greater consolidation occurred in MFT amended with $\mathrm{FeCl}_{2}$ compared to untreated MFT, followed by the effects of $\mathrm{CaCl}_{2}$ and then $\mathrm{NaCl}$; maximum consolidation was achieved using $6 \mathrm{~N} \mathrm{HCl}(\mathrm{pH} 1)$. These results support our proposed biogeochemical model (Pathway I, Figure 7), in that: (1) increased $I$ of the MFT decreased DDL of clay particles; (2) divalent cations can exchange monovalent cations from exchanger surfaces (although not observed in current study, this was a significant effect in an acetate-amended 2-L MFT column study; Arkell et al., in review), thereby decreasing DDL; and (3) lower MFT pH dissolved carbonate minerals and changed $\mathrm{pH}$-dependent charges on clays, leading to consolidation of MFT.

The results of this study are important for the management of oil sands tailings. Microbially-enhanced tailings consolidation apparently is occurring in situ (Fedorak et al., 2003), likely supported by endogenous substrates such as light hydrocarbons used in bitumen extraction, where concomitant recovery of porewater can decrease on-site demand for freshwater for oil sand ore processing. Biodensification may also facilitate dry landscape reclamation of MFT by complementing or possibly foregoing current chemical and physical management practices like chemical flocculant addition and energy-intensive centrifugation processes. In 


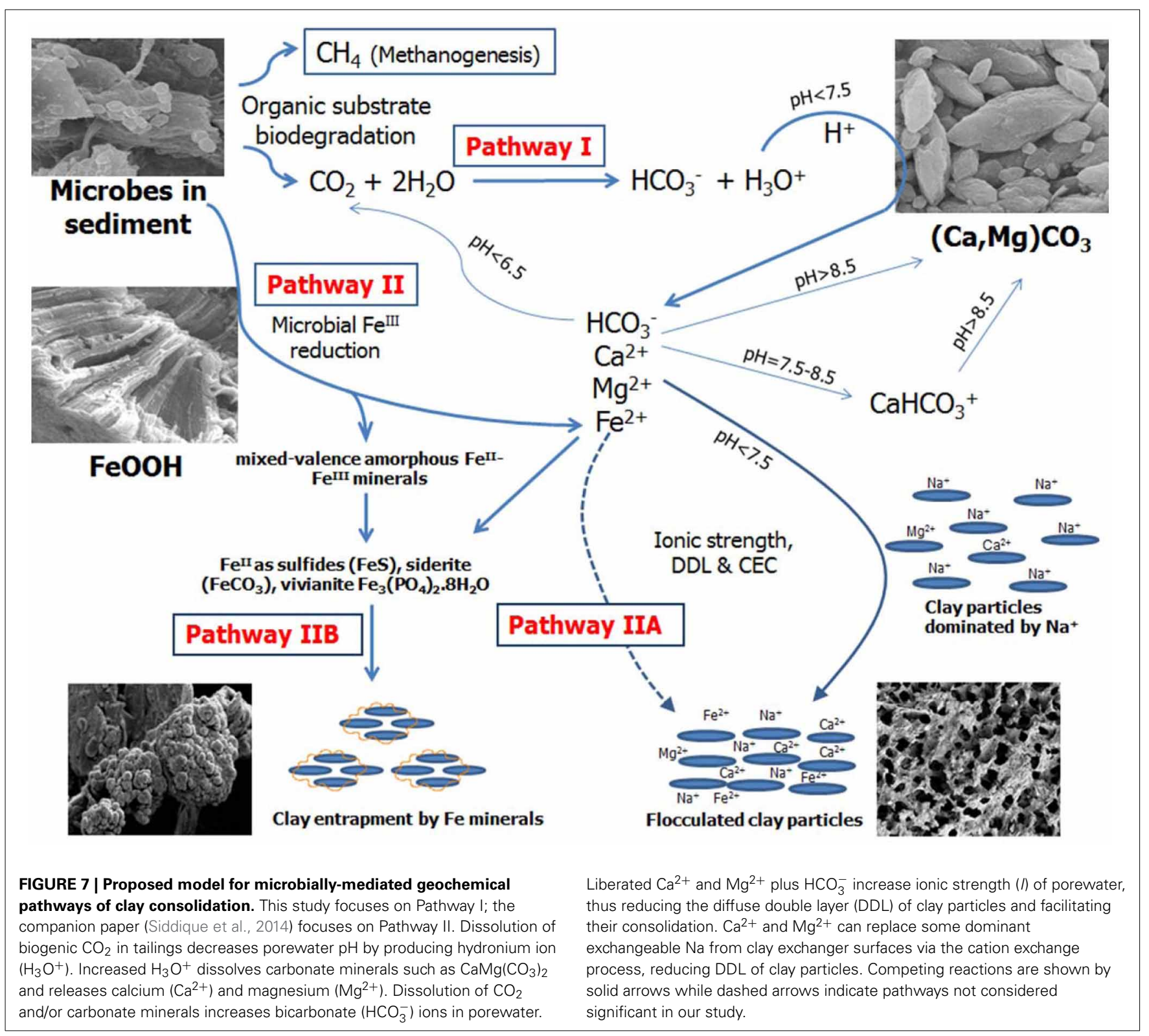

addition to oil sands tailings, it would be prudent to consider the roles of indigenous microbes in the consolidation of other organic-rich soft sediments, such as those in contaminated harbors and river deltas, and to incorporate biological factors into consolidation models.

\section{ACKNOWLEDGMENTS}

We gratefully acknowledge funding from Alberta InnovatesEnergy and Environment Solutions (Tariq Siddique, Selma Guigard, Julia M. Foght), Genome Canada (Julia M. Foght), Helmholtz-Alberta Initiative (Tariq Siddique, Julia M. Foght), NSERC Discovery Grants (Tariq Siddique, Julia M. Foght) and the School of Energy and the Environment (Julia M. Foght, Tariq Siddique). We thank Syncrude Canada Ltd. for providing tailings and Sanimax for providing dried canola meal. At the University of Alberta, we thank Kathleen Semple for technical assistance and Phillip Fedorak and David Bressler for discussions.

\section{SUPPLEMENTARY MATERIAL}

The Supplementary Material for this article can be found online at: http://journal.frontiersin.org/journal/10.3389/fmicb. 2014.00106/abstract

\section{REFERENCES}

Alberta Environment and Sustainable Resource Development. (2013). Oil sands landcover status 2011. Edmonton, AB: AERSD 1995

Boone, D. R. (1982). Terminal reactions in the anaerobic digestion of animal waste. Appl. Environ. Microbiol. 43, 57-64.

Bressler, D., Cardenas, M., Fedorak, P. M., Guigard, S., Gupta, R., Siddique, T., et al. (2010). "Microorganisms in oil sand tailings ponds influence the properties and behaviour of mature fine tailings," in Proceedings of 2nd International Oil Sands Tailings Conference (Edmonton, AB), 44. 
Brown, D., Ramos-Padrón, E., Gieg, L., and Voordouw, G. (2013). Effect of calcium ions and anaerobic microbial activity on sedimentation of oil sands tailings. Int. Biodeterior. Biodegradation 81, 9-16. doi: 10.1016/j.ibiod.2012.07.006

Carter, M. R., and Gregorich, E. G. (2008). Soil Sampling and Methods of Analysis. Can. Soc. Soil Sci. Oxford: CRC Press.

Chou, L., Garrels, R. M., and Wollast, R. (1989). Comparative study of the kinetics and mechanisms of dissolution of carbonate minerals. Chem. Geol. 78, 269-282. doi: 10.1016/0009-2541(89)90063-6

Dean, E. W., and Stark, D. D. (1920). A convenient method for the determination of water in petroleum and other organic emulsions. Ind. Eng. Chem. 12, 486-490. doi: 10.1021/ie50125a025

Eslinger, E., Highsmith, P., Albers, D., and De Mayo, B. (1979). Role of iron reduction in the conversion of smectite to illite in bentonites in the disturbed belt, Montana. Clays Clay Miner. 27, 327-338. doi: 10.1346/CCMN.1979.0270503

Essington, M. E. (2004). Soil and Water Chemistry: An Integrative Approach. Boca Raton, FL: CRC Press LLC.

Fedorak, P. M., Coy, D. L., Dudas, M. J., Simpson, M. J., Renneberg, A. J., and MacKinnon, M. D. (2003). Microbially-mediated fugitive gas production from oil sands tailings and increased tailings densification rates. J. Environ. Eng. Sci. 2, 199-211. doi: 10.1139/s03-022

Fotidis, I. A., Karakashev, D., Kotsopoulos, T. A., Martzopoulos, G. G., and Angelidaki, I. (2013). Effect of ammonium and acetate on methanogenic pathway and methanogenic community composition. FEMS Microbiol. Ecol. 83, 38-48. doi: 10.1111/j.1574-6941.2012.01456.x

Himmelheber, D. W., Pennell, K. D., and Hughes, J. B. (2011). Evaluation of a laboratory-scale bioreactive in situ sediment cap for the treatment of organic contaminants. Water Res. 45, 5365-5374. doi: 10.1016/j.watres.2011.06.022

ISO 11465. (1993). Soil Quality - Determination of Dry Matter and Water Content on a Mass Basis - Gravimetric Method. Geneva: Int. Org. Standard.

Jeeravipoolvarn, S., Scott, J. D., and Chalaturnyk, R. J. (2009). $10 \mathrm{~m}$ standpipe tests on oil sands tailings: long term experimental results and prediction. Can. Geotech. J. 46, 875-888. doi: 10.1139/T09-033

Jensen, D. L., Boddum, J. K., Tjell, J. C., and Christensen, T. H. (2002). The solubility of rhodochrosite $\left(\mathrm{MnCO}_{3}\right)$ and siderite $\left(\mathrm{FeCO}_{3}\right)$ in anaerobic aquatic environments. Appl. Geochem. 17, 503-511. doi: 10.1016/S0883-2927(01)00118-4

Mietta, F., Chassagne, C., and Winterwerp, J. C. (2009). Shear-induced flocculation of a suspension of kaolinite as function of $\mathrm{pH}$ and salt concentration. J. Colloid Interface Sci. 336, 134-141. doi: 10.1016/j.jcis.2009.03.044

Morse, J. W., Arvidson, R. S., and Lüttge, A. (2007). Calcium carbonate formation and dissolution. Chem. Rev. 107, 342-381. doi: 10.1021/cr050358j

Moulin, E., Jordens, A., and Wollast, R. (1985). "Influence of the aerobic bacterial respiration on the early dissolution of carbonates in coastal sediments," in Progress in Belgian Oceanographic Research, eds R. Van Grieken and R. Wollast (Brusells: University of Antwerpen), 196-208.

Nasser, M. S., and James, A. E. (2006). The effect of polyacrylamide charge density and molecular weight on the flocculation and sedimentation behaviour of kaolinite suspensions. Sep. Purif. Technol. 52, 241-252. doi: 10.1016/j.seppur.2006.04.005

Pansu, M., and Gautheyrou, J. (2006). Handbook of Soil Analysis. Mineralogical, Organic and Inorganic Methods. Berlin; Heidelberg: Springer-Verlag. doi: 10.1007/978-3-540-31211-6

Penner, T. J., and Foght, J. M. (2010). Mature fine tailings from oil sands processing harbour diverse methanogenic communities. Can. J. Microbiol. 56, 459-470. doi: 10.1139/W10-029

Rayment, G. E., and Lyons, D. J. (2012). New, comprehensive soil chemical methods book for Australasia. Commun. Soil Sci. Plant Anal. 43, 412-418. doi: 10.1080/00103624.2012.641802

Roberts, D. J. (2002). "Methods for assessing anaerobic biodegradation potential," in Manual of Environmental Microbiology, eds C. J. Hurst, R. L. Crawford, G. R. Knudson, M. J. McInerney, and L. D. Stetzenbach (Washington, DC: ASM Press), 1008-1017.

Schlegel, M. E., McIntosh, J. C., Bates, B. L., Kirk, M. F., and Martini, A. M. (2011). Comparison of fluid geochemistry and microbiology of multiple organic-rich reservoirs in the Illinois Basin, USA: evidence for controls on methanogenesis and microbial transport. Geochim. Cosmochim. Acta 75, 1903-1919. doi: 10.1016/j.gca.2011.01.016
Schramm, L. L., Stasiuk, E. N., and MacKinnon, M. D. (2000). "Surfactants in Athabasca oil sands slurry conditioning, flotation recovery, and tailings processes," in Surfactants, Fundamentals, and Applications in the Petroleum Industry, ed L. L. Schramm (Cambridge: Cambridge University Press), 365-430. doi: 10.1017/CBO9780511524844.011

Shen, S., and Stucki, J. (1994). "Effects of iron oxidation state on the fate and behavior of potassium in soils," in Soil Testing: Prospects for Improving Nutrient Recommendations, eds J. L. Havlin and J. S. Jacobsen (Madison, WI: SSSA Special Publication 40), 173-185.

Siddique, T., Fedorak, P. M., and Foght, J. M. (2006). Biodegradation of shortchain n-alkanes in oil sands tailings under methanogenic conditions. Environ. Sci. Technol. 40, 5459-5464. doi: 10.1021/es060993m

Siddique, T., Fedorak, P. M., Mackinnon, M. D., and Foght, J. M. (2007) Metabolism of BTEX and naphtha compounds to methane in oil sands tailings. Environ. Sci. Technol. 41, 2350-2356. doi: 10.1021/es062852q

Siddique, T., Kuznetsov, P., Kuznetsova, A., Li, C., Young, R., Arocena, J. M., et al. (2014). Microbially-accelerated consolidation of oil sands tailings. Pathway II: solid phase biogeochemistry. Front. Microbiol. 5:107. doi: 10.3389/fmicb.2014. 00107

Siddique, T., Penner, T., Klassen, J., Nesbø, C., and Foght, J. M. (2012). Microbial communities involved in methane production from hydrocarbons in oil sands tailings. Environ. Sci. Technol. 46, 9802-9810. doi: 10.1021/es302202c

Siddique, T., Penner, T., Semple, K., and Foght, J. M. (2011). Anaerobic biodegradation of longer-chain $\mathrm{n}$-alkanes coupled to methane production in oil sands tailings. Environ. Sci. Technol. 45, 5892-5899. doi: 10.1021/es20 0649t

So, H., Menzies, N., Bigwood, R., and Kopittke, P. (2006). Examination into the accuracy of exchangeable cation measurement in saline soils. Commun. Soil Sci. Plant Anal. 37, 1819-1832. doi: 10.1080/00103620600762927

Sparks, D. L. (1996). Methods of Soil Analysis: Part 3. Chemical Methods. Madison, WI: SSSA.

US EPA. (1974). Method 310.2. Alkalinity (Colorimetric, Automated, Methyl Orange). Available online at: http://water.epa.gov/scitech/ methods/cwa/methods_index.cfm

US EPA. (1993). Method 365.1 Revision 2.0. Determination of Phosphorous by Semi-Automated Colorimetry. Available online at: http://water.epa.gov/ scitech/methods/cwa/methods_index.cfm

Voordouw, G. (2013). Interaction of oil sands tailings particles with polymers and microbial cells: first steps toward reclamation to soil. Biopolymers 99, 257-262. doi: 10.1002/bip.22156

Wersin, P., Leupin, O. X., Mettler, S., Gaucher, E. C., Mäder, U., De Cannière, P., et al. (2011). Biogeochemical processes in a clay formation in situ experiment: part A - overview, experimental design and water data of an experiment in the Opalinus Clay at the Mont Terri Underground Research Laboratory, Switzerland. Appl. Geochem. 26, 931-953. doi: 10.1016/j.apgeochem.2011.03.004

Conflict of Interest Statement: The authors declare that the research was conducted in the absence of any commercial or financial relationships that could be construed as a potential conflict of interest.

Received: 03 December 2013; accepted: 02 March 2014; published online: 21 March 2014.

Citation: Siddique T, Kuznetsov P, Kuznetsova A, Arkell N, Young R, Li C, Guigard S, Underwood E and Foght JM (2014) Microbially-accelerated consolidation of oil sands tailings. Pathway I: changes in porewater chemistry. Front. Microbiol. 5:106. doi: 10.3389/fmicb.2014.00106

This article was submitted to Microbiological Chemistry, a section of the journal Frontiers in Microbiology.

Copyright (c) 2014 Siddique, Kuznetsov, Kuznetsova, Arkell, Young, Li, Guigard, Underwood and Foght. This is an open-access article distributed under the terms of the Creative Commons Attribution License (CC BY). The use, distribution or reproduction in other forums is permitted, provided the original author(s) or licensor are credited and that the original publication in this journal is cited, in accordance with accepted academic practice. No use, distribution or reproduction is permitted which does not comply with these terms. 